\title{
Event museum events as a factor in increasing the tourist attractiveness of the Rostov region
}

\author{
Galina Ekinil $^{1 *}$, Antonina Petrenko ${ }^{1}$, Ekaterina Davydova $^{1}$ \\ ${ }^{1}$ Don State Technical University, Gagarina Sq., 1, Rostov-on-Don, 344000, Russia
}

\begin{abstract}
This study aims to identify the role of event museum events in the development of tourist attractiveness of the Rostov region. The article describes the museum network of the Rostov region, considers ways to attract tourists to the region; types of events are considered, features of museum events are investigated, stages of the organization of events are resulted, the successful experience of development of museum events in the Rostov region is described, and also tendencies of development of events museum actions are defined.
\end{abstract}

\section{Introduction}

World practice shows that the museum industry, using modern marketing and PR technologies, can become attractive to new visitors. The task of maintaining its target audience, supporting the constant interest of the new audience in their activities is relevant for many museums. According to statistics, the factor of museum attendance by the audience is key in the formation of extra-budgetary revenues of museums. In the last few decades, the non-profit sphere, which includes museums, has adopted marketing tools.

Event events are essentially a marketing phenomenon, the essence of which is to form an emotional positive attachment in a potential client to the image of the product, the brand of the service, which occurs during the participation in the event. Events should always be thematic.

Understanding the culture of a nation, people, or group - art, beliefs, customs, practices, values, and social behavior - underpins human existence. By taking a direct part in mass events, people personally get acquainted with the diversity of cultural and artistic creativity in society.

Education and educational knowledge cannot take place only in educational institutions - the cognitive process is constant, a person replenishes his baggage of understanding the world every day in various forms. Watching a live performance is a completely different experience than reading a work from a book. By participating in activities, a person broadens his/her horizons and acquires unique knowledge in his / her communities, sees a broader perspective of different cultures of the world.

Raising the cultural level, development of creative talents and abilities, formation of moral, aesthetic and physical appearance of a person are event activities.

Hedonistic, entertaining, educational, creative, communicative, axiological functions. In

* Corresponding author: gekinil@mail.ru 
other words, such an event should not only be economically profitable, but also carry a socio-cultural creative message. Mass cultural and leisure events have their own peculiarities: access to them is open, such events are difficult to withstand within the prescribed scenario. However, the advantage of mass events is that they provide an opportunity to include a sense of belonging in the process. Mass events are also quite successful in the format of a holiday.

By organizing special events, unusual, bright and memorable events, organizations take an active part in the social life of their target audience.

Event events to attract mass interest arose thousands of years ago. Thus, in ancient Rome found two important levers of control - bread and spectacles. And the technological technique called "organized event", which has a powerful emotional impact on the target audience, has remained relevant. It is known that the first events in the history of society were most likely ancient social and religious rituals. Over the centuries, events have become more sophisticated and difficult.

City-wide and public holidays, coronations, and significant religious events spanning entire continents began to appear.

All this points to the urgency of the topic and requires further study. attractiveness of the Rostov region.

To achieve this goal, the following tasks were solved in the work: the characteristics of the museum network of the Rostov region are given; ways to attract tourists to the region are considered; types of event actions are considered; features of museum events are investigated; the stages of the organization of event actions are resulted; describes the successful experience of the development of museum events in the Rostov region, as well as identifies trends in the development of museum events.

\section{Materials and methods}

Event events are a systematic organization of events designed to present goods or services, and aimed at emotional impact and activation of the target audience's attention to this product or service. With the help of such activities, the usual, routine course of the organization's life is disrupted and active participation in the public life of its target groups begins, bringing their services much closer to potential consumers.

But, despite the energetic work and implementation of events, often to explain the essence of this phenomenon in an open form it is necessary to refer to the organization of special events, holidays, exhibitions, presentations. The most important goal of a current and productive event is to involve the target audience in the event.

Among the events can be identified internal and external types of communication with the target audience. Internal communication is aimed at the staff of the organization, partners, sponsors, in order to develop and promote the organization in the market. The active development in the successful organization of event museum events is influenced by interested consumers - the target audience of external communication of event events.

There are three main features of an event:

- a large number of people;

- organization of actions;

- the presence of a goal (Fig. 1). 


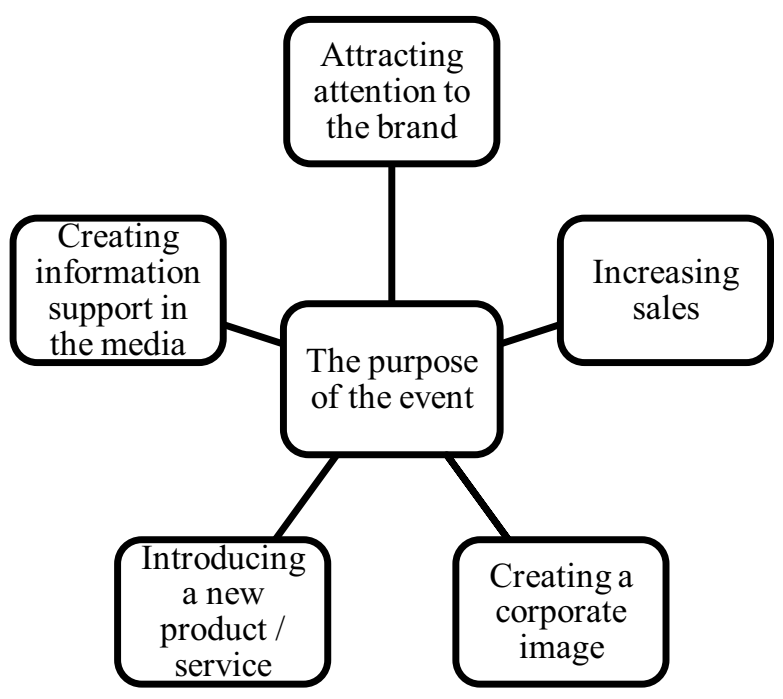

Fig. 1. The purpose of the event.

In modern society, a sufficient amount of practical experience has been accumulated in the field of holding mass events. Over the years, certain cultural traditions have developed, basic forms and techniques have been formed. - small-scale - ritual and ceremonial processions.

For successful realization of the concept of event marketing the choice of type of event and action becomes an actual problem. There is no unambiguous classification of events and activities in the scientific literature, as the event model is multi-attributive.

Event events can be divided into the following types according to the classifier:

- by periodicity (single, multiple);

- place of formation (internal, external);

- method of initiation (natural / genuine, artificial / special).

It is possible to classify by other criteria, such as: audience of influence; form of participation; the type and form of the event; the nature of the interaction (formal, informal), etc. However, it is important to understand that each event is individual and has a number of characteristics that are unique to a particular organization.

Event marketing tools are often limited only by the imagination of the organizers themselves. The application of a differentiated approach in determining and choosing the type and form of activities depending on the required results, based on the above classification, which allows us to talk about their more effective impact as an event marketing tool on the target audience in accordance with real goals.

It should be borne in mind that the organization and holding of mass events creates a special environment in this area, which has the following features:

- the usual rhythm of life of the population is broken (restriction of traffic, change of a mode of work of the commercial enterprises, public catering, household service, etc.);

- the presence of a large mass of people in a limited area, where various restrictions have been imposed, means that citizens can be influenced by the so-called «crowd psychology». This influence is expressed in the fact that people become prone to the perception of all kinds of rumors and gossip, less self-critical about their own actions, more excited and irritable.

Among foreign authors, the problems of event tourism were dealt with Y. Mansour, H. 
Sabry, M. Refat, A. Wagdy, 2020 [1], C. Fenu, F. Pittarello, 2018 [2], B. I. Farahat, K.A. Osman, 2018 [3], X. Luo, P. Song, Y. Wang, W. Tian, Z. Gu, 2016 [4], M. Napp, T. Kalamees, T. Tark, E. Arumägi, 2016 [5], J. Pallud, D. W. Straub, 2014 [6].

The methods of tourism research in the context of regional specifics are devoted to the works of such authors as: S. Karampela, D. Kavroudakis, T. Kizos, 2019 (the experience of Greece) [7], T.Y. Dewanti, D. Susiloningtyas, Supriatna, 2019, (the experience of Indonesia) [8], S. Li, C. Li, J. Li, 2019, (the experience of China) [9], J. Cheng, JingXu, ZhenfangHuang, 2019 [10], SamiChaabouni, 2019 [11], VirgilNicula, SimonaSpânu, RoxanaElenaNeagu, 2013, (the experience of Romania) [12], DanielaDoinaFundeanu, 2015 [13], H.A.M. Shaffril, A. Hamzah, S.Md. Yassin, B.A. Samah, J.L. D’Silva, N. Tiraieyari, M. Muhammad [14]. Thanks to their research, this type of tourism has become an independent branch of science with its own terminology and has become a separate area.

On the other hand, the features of innovations in the tourism and hospitality industries, reflected in the works, were studied: S. Wang, K.Hung 2015 [15], Ivanov V., Popov S., Dontsov N., Ekinil G., Oleynikova Ju., Denisenko Ju. 2020 [16], Valeria Provotorina, Lyudmila Kazmina, Antonina Petrenko, Galina Ekinil 2020 [17], Galina Ekinil, Lyubov Gorgadze and Oksana Yuryeva [18] A. Mai Walder, 2017 [19], J.Chun-Chung Chow, Cheng Ren, Brenda Mathias, Jiaying Liu 2019 [20], Meiju Keinänen, Jani Ursin, Kari Nissinen 2018 [21], Viv Ellis, Ann Childs 2019 [22], Nicole C.Jackson 2019 [23], Ekinil, G., Gorgadze, L., Provotorina, V., Petrenko, A. [24, 25].

Methodological approaches such as complex, systemic and institutional, can be used in the organization of event museum events, as they provide an opportunity to study the main trends in the development of museum activities. The study also uses a typological approach, which allows to characterize not only the current trends and constraints on the development of museum events, but also to identify possible prospects for development. The scientific provisions, conclusions and recommendations contained in the article are based on the use of combined methods of historical and logical analysis.

\section{Results}

The Rostov region is the beginning of the south of Russia, which includes about 800 objects of the tourism industry and more than eight thousand archeological objects of cultural heritage. Annually, the Rostov region is visited by about a million tourists. The main type of tourism in the Rostov region is cultural and cognitive, as well as developing business, environmental, rural, water and other types of tourism.

The museum network of the Rostov region consists of 63 museums. Among them, a special place is occupied by museums-reserves and memorial museums associated with famous natives of the region: MA Sholokhov, AP Chekhov, A. Kalinin, A. Solzhenitsyn, Emperor Alexander I, military leaders A. Suvorov, S. Budyonny and others.

Local history, history and thematic museums have become widespread. The composition of the museum network of the Rostov region is shown in Fig. 2.

The beginning and further development of events in the Rostov region belongs to museums, they were the first to use their sites for events, both regional and federal significance. The thematic orientation of six museums-reserves of the Rostov region became the basis of excursion and tourist programs. The beginning and further development of events in the Rostov region belongs to museums.

Recognition of the territory, famous names, historical events are used when planning museum events. Table 1 shows the main event museum events of the museums of the Rostov region. 


\section{Museum network of the Rostov}

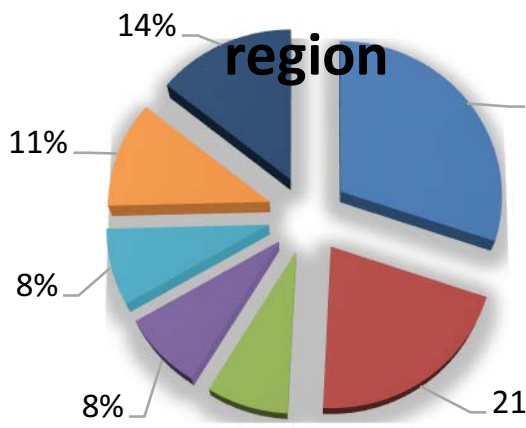

$30 \%$

Local history

- Artistic

- Others

\section{$8 \%$}

Memorial, personal

- Scientific and technical
Historical

Museums-reserves

Fig. 2. Museum network of the Rostov region.

Museums actively use interactive programs during events, the theme of which reveals the cultural and historical significance of the region. Such actions raise national selfawareness and help attract tourists to the region. Interest in the local color and traditions of the Cossacks, impressions of event museum events contribute to the growth of unorganized tourists.

Table 1. The main event museum events of the museums of the Rostov region.

\begin{tabular}{|c|c|c|c|}
\hline № & Name of the museum & Event & Note \\
\hline 1 & $\begin{array}{l}\text { State Museum-Reserve M.A. } \\
\text { Sholokhov }\end{array}$ & «Sholokhov Spring» & $\begin{array}{c}\text { Held since the } 80 \text { s of last century annually in } \\
\text { May, attended by about } 100 \text { thousand. tourists } \\
\text { and excursionists. }\end{array}$ \\
\hline 2 & Azov Museum-Reserve & $\begin{array}{c}\text { Reconstructions of historical } \\
\text { events }\end{array}$ & $\begin{array}{c}\text { On the ramparts - the site of the Azov siege of } \\
\text { the Don Cossacks in } 1641 \text { - annually } \\
\text { reconstructs the heroic events of the XVII } \\
\text { century. }\end{array}$ \\
\hline 3 & $\begin{array}{l}\text { Archaeological Museum- } \\
\text { Reserve «Tanais» }\end{array}$ & Museum theatrical festivals & $\begin{array}{l}\text { In the spirit of the «time machine» annually } \\
\text { organizes theatrical celebrations, allowing all } \\
\text { participants to feel like inhabitants of the } \\
\text { ancient Greek city-polis. }\end{array}$ \\
\hline \multirow[b]{2}{*}{4} & \multirow{2}{*}{$\begin{array}{l}\text { Razdor Ethnographic } \\
\text { Museum-Reserve }\end{array}$} & Kalinin Summer Festival & $\begin{array}{l}\text { The novel «Gypsy» attracts fans of the talent } \\
\text { of the Don writer A. Kalinin, gathering guests } \\
\text { in the Ust-Donetsk region. }\end{array}$ \\
\hline & & Don Vine Festival & $\begin{array}{l}\text { The summer tourist season of the Rostov } \\
\text { region comes to an end in the Pukhlyakovsky } \\
\text { farm, a holiday of Don viticulture and } \\
\text { winemaking. }\end{array}$ \\
\hline 5 & $\begin{array}{l}\text { Starocherkasy Museum- } \\
\text { Reserve }\end{array}$ & Folklore Festivals & $\begin{array}{c}\text { Annual air show in the village of Olginskaya, } \\
\text { a fair of souvenirs and local artists. }\end{array}$ \\
\hline 6 & $\begin{array}{l}\text { Ethno-Archaeological } \\
\text { Complex «Lost World» }\end{array}$ & «Trail stories» & $\begin{array}{l}\text { The only museum of archeological } \\
\text { reconstruction in the south of Russia. } \\
\text { Ethnographic materials and finds are } \\
\text { presented here. }\end{array}$ \\
\hline
\end{tabular}


Within the framework of the state program «Development of Culture and Tourism» more than $60 \%$ of the allocated budget is provided as measures to attract tourists to the Don region. In 2020, the People's Military-Historical Museum Complex of the Great Patriotic War «Sambek Heights» was created, which can become a platform for the organization of military reconstructions and museum events. This will contribute to the patriotic education of young people and attract tourists to the Don region.

To increase the competitiveness of the regional tourism product, as well as the formation of an attractive tourist image of the Rostov region, it is necessary to ensure the availability of information about museum events.

Table 2 shows the comparative characteristics of the main indicators of the tourism industry of the Rostov region according to Rosstat.

Table 2. Comparative characteristics of the main indicators of the tourism industry of the Rostov region.

\begin{tabular}{|c|c|c|c|}
\hline$№$ & Indicator & Plan & Actual implementation \\
\hline 1 & Income of collective accommodation & 3,8 billion rubles & 1,8 billion rubles \\
\hline 2 & $\begin{array}{c}\text { Number of citizens accommodated in } \\
\text { hotels }\end{array}$ & 789 thousand person & 646 thousand person \\
\hline 3 & $\begin{array}{c}\text { Foreign citizens accommodated in } \\
\text { hotels }\end{array}$ & 74,1 thousand person & 25,6 thousand person \\
\hline 4 & $\begin{array}{c}\text { Number of visits to regional theaters, } \\
\text { concert organizations, museums and } \\
\text { libraries per 1000 people }\end{array}$ & 849 person & 634 person \\
\hline 5 & $\begin{array}{c}\text { Share of exhibited museum objects in } \\
\text { the total number of museum objects of } \\
\text { the fixed fund }\end{array}$ & $11,3 \%$ & $11,1 \%$ \\
\hline 6 & $\begin{array}{c}\text { Share of museum objects included in } \\
\text { the electronic catalog of the total } \\
\text { number of fixed assets }\end{array}$ & $100 \%$ & $2,6 \%$ \\
\hline 7 & $\begin{array}{c}\text { Share of restored museum objects in } \\
\text { the total volume to be restored }\end{array}$ & $2,6 \%$ & 3 units \\
\hline 8 & $\begin{array}{c}\text { Number of exchange exhibitions } \\
\text { between museums of the Rostov } \\
\text { region and museums of the Russian } \\
\text { Federation }\end{array}$ & $6,7 \%$ & $2,34 \%$ \\
\hline 9 & $\begin{array}{c}\text { Growth rate of the number of } \\
\text { participants in cultural and leisure } \\
\text { events }\end{array}$ & & \\
\hline
\end{tabular}

Thus, in 2020, the process of organizing and conducting events was influenced by restrictive measures related to the suspension of mass events in the Rostov region to prevent the spread of coronavirus infection COVID-19. The hospitality industry, including museums, is among the most affected by the pandemic industries. The decline in outbound and inbound tourism in 2020 was about $80 \%$.

\section{Discussion}

Museums live a special creative life, each page of which is connected with the history of the city and the Don region. Understanding the Motherland, awareness of cultural values, material and production assets have always been a spiritual need of people. And today, in the turbulent flow of rapidly flowing events, the museum is a necessary link that helps to understand the essence of social phenomena, gain faith in human moral values and educate real citizens and patriots of their homeland. A modern visitor comes to the museum to 
learn. He easily goes to the dialogue, is actively involved in the dispute, so the approach to it requires an individual, taking into account age, education, social affiliation. Hence the task of the museum staff - to create an atmosphere of psychological and intellectual comfort. Implementing this task, the museum staff organizes work in close cooperation with the city's educational institutions. Much attention is paid to children from low-income and large families, children with disabilities, free events, theatrical performances, etc. are held for them. The range of cultural and mass activities of employees is not limited to the walls of the museum. New forms of work are actively used, such as traveling exhibitions in schools, orphanages, lessons-excursions. The social significance of museums and the efficiency of their activities is increased through the introduction of various forms of work and types of educational activities. The last few years have seen an expansion of the museum's audience.

According to individually developed programs for pupils of kindergartens, boarding schools, general education schools, various activities are held in accordance with the state social directions.

Mass events in all their diversity and all varieties $\square$ an unusually complex culturological phenomenon. At first glance, the organization of events does not seem to be a complicated process, giving the impression of a purely technical work. In fact, this is one of the most difficult areas of event marketing, which hides the intense, time-consuming preliminary work of the event manager. City holidays and any other events, which are attended by a large number of people, instantly gain scale and significance, and at the same time a huge responsibility for the organizers. In a short period of time, the participants should have time to receive and analyze a large amount of information, discuss important issues and, of course, work out ways to solve them.

It is possible to organize an interesting, large-scale event only starting from its main goal and common tasks, creating the most comfortable, cozy and favorable conditions for all participants and guests of the event.

In the process of preparation for the organization of a mass event, due attention should be paid to the development of the scenario of the event, the selection of the place where the event will be held. It is also very important to carry out the design concept, if necessary, interaction with catering establishments (outreach services), as well as the organization of security of all participants.

First of all, it is necessary to pay attention to the process of planning the main stages of the event, taking into account some parameters:

- timeliness, which is the right place for the organization of the event and time for its holding;

- grandeur, the use of action elements that delight the audience and all participants of the event;

- opportunity to relax, as participants come to such events to relax, to distract from the daily hustle and bustle. In this regard, you should not overdo it with unnecessary information, constant attention to your products, goods, brand;

- involvement. Maximum participation in interactive game zones, joint performance of songs, invitation of participants to the stage will give positive emotions and pleasant memories;

- the presence of resonance. Various rumors, alerts and articles that help to talk about the event both before and after it.

Important in the organization of mass events are components such as: method of preparation, form, thematic focus, age range of the target audience, scale.

It is necessary to understand and clearly formulate the purpose of the event, organize training in accordance with the goal, choose the best methods and techniques, rhythm and pace of the event, provide elements of surprise, provide a variety of forms and creative 
nature of participants, build relationships. 3).

Effective organization and holding of a mass event must be carried out in stages (Fig.

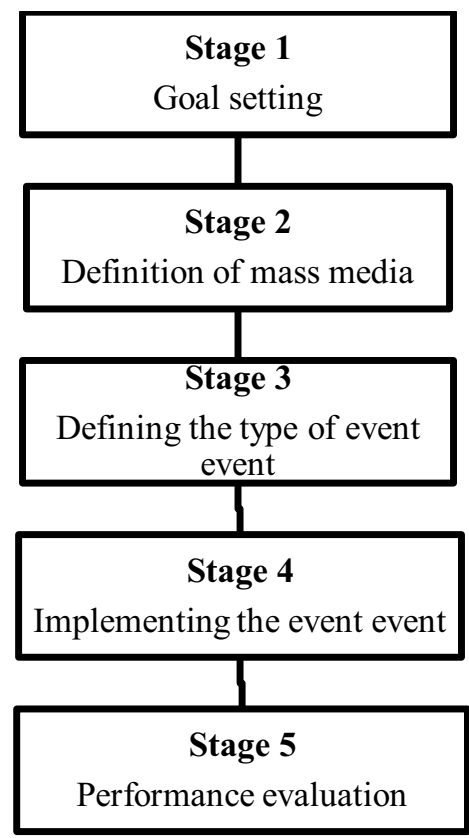

Fig. 3. Stages of organizing and conducting a mass event.

Detailed elaboration of a step-by-step plan for the event involves answering the following important questions: who and how we invite, where and what we do. The process includes five main stages.

At the first stage the statement of the purpose of the organization and carrying out of event action is carried out. Before starting the event, it is necessary to determine the target audience, venue and determine the organizations that will participate in the event as organizers and sponsors.

It is necessary to think about the purposes and tasks at the nascent stages. The format of the holiday as a whole and its individual nuances will depend on it. The main thing is that the target audience was interested. Interest is the key point. As a rule, two main mistakes are made here:

- the event carries no semantic load and is created just like that, for noise, a show to just do something, and the marketing aspects of the event are not taken into account. It either does not cover the audience of interest, or lacks any value and meaning for it;

- when organizing events, digging often pursues its own interests, and focuses on demonstrating themselves, forgetting the interests of consumers. That is, the consumer loses all interest in the product when the event is oversaturated with brand advertising.

The choice of venue as well as time play an important role in organizing an event. Wrongly chosen time may not allow the target audience to attend the event; the wrong place (the ability to get to your destination) can scare off potential consumers and attract unnecessary audiences.

When deciding on the date and duration, it is important to consider the following time factors:

- time of year and weather conditions, respectively;

- holidays and weekends (parallel events). 
The first stage of creating an event is incredibly lively and creative, it involves all employees, brainstorming, a sea of proposals, sometimes crazy ideas, which then take shape.

The second stage identifies the media that will be effective for of the implemented event. At this stage, the work of marketing and team management is intensified, information partners are selected. The key concise message, which will be broadcast on all selected communication channels, will support the announcement of the event.

The third stage includes all the components of the event, which laid the foundations for building the process of its organization. This stage is aimed at determining the type of event that will meet the content and technological requirements, elements of the technological process of creating an event, as well as the development of technology for organizing the event.

The fourth stage is the immediate implementation of the event, this is the period of its implementation, which may depend on human behavior and opinion. This characteristic should take into account the most important factors influencing consumer behavior:

- cultural factors determined by ethno-national, normative-value traditions, subculture, social status;

- social group factors that are determined by the social roles of individuals, family, reference groups;

- personal factors determined by age (physical and personal-psychological), profession, economic status, lifestyle, personality type and self-esteem;

- psychological factors determined by attitude, attitudes, perception, thinking, temperament.

The main thing in organizing and conducting an event - awareness of the real motivations of the consumer. Success in business does not depend on the ability to solve well-structured tasks with explicit parameters, but on the ability to take into account and use implicit advantages.

The fifth stage reflects the quantitative and qualitative indicators of the event and its impact on socio-economic development. The crucial point is to achieve the goal originally set for the organization (Table 3).

Table 3. The effectiveness of the organization of events.

\begin{tabular}{|c|c|}
\hline Purpose & Efficiency \\
\hline $\begin{array}{c}\text { making a profit directly from the event (selling } \\
\text { something) }\end{array}$ & $\begin{array}{c}\text { number of products sold and the ratio of } \\
\text { income from the event and its costs }\end{array}$ \\
\hline $\begin{array}{c}\text { increasing profit in the short or medium term } \\
\text { problem }\end{array}$ & $\begin{array}{c}\text { sales growth, increase in the number of } \\
\text { customers }\end{array}$ \\
\hline $\begin{array}{c}\text { drawing public attention to a product, service or } \\
\text { presentation of a new product (service) }\end{array}$ & number of media mentions \\
\hline $\begin{array}{c}\text { Informing, training and sharing experiences } \\
\text { between participants }\end{array}$ & $\begin{array}{c}\text { increasing the level of competence and } \\
\text { professional literacy of the participants of the } \\
\text { event }\end{array}$ \\
\hline $\begin{array}{c}\text { Finding partners and expanding business } \\
\text { relationships }\end{array}$ & $\begin{array}{c}\text { the number of new partners ready for business } \\
\text { interaction }\end{array}$ \\
\hline
\end{tabular}

Assessing the effectiveness of the events is an important component of the marketing policy process, which is to track the impact of selected methods of marketing communications on the process of capital growth. Usually the results are presented in the 
form of analysis of questionnaires for evaluation of participants, preparation of statistical analysis of participants, analysis of the event project in terms of organization and recommendations for follow-up, analysis of media activity, preparation of analytical report on the event and sending letters of thanks to all participants.

The order of the event must provide a clear organization of the movement of events, the rules of consideration of issues, forms of completion of the substantive part, the definition of procedural issues, ie display of time-verified structure of the content of the event. This procedure is considered an integral part of both regular and irregular activities [14].

Thus, the event has a complex structure, expressed in quality organizations. Despite the complex organization of the process, the organization and holding of events is becoming an increasingly popular method, gaining momentum among businesses that are important to hold an event to achieve their marketing goals. In the formation of the image of the enterprise - this is one of the most effective tools. The best effect as a result of holding and organizing an event is the fact that the consumer, the participant of the event, did not realize that he was exposed to advertising technologies, because the professional approach to planning and conducting projects, they should not be noticeable.

The interactive portal «Don Tourism» is the main information resource of the Rostov region. Here are guides to the region, marked museums, architectural complexes, attractions, a calendar of events. The structure of the portal includes all information about the activities of the tourism development department, contains information about social tours, mass events, seminars and competitions.

Event museum events as a factor in attracting tourists when used correctly work at the economic and social level. The socio-economic effect of the implementation of event museum events in the field of tourism in the Rostov region can provide an increase in tourists by more than $15 \%$ and an increase in the volume of paid services in the field of tourism. Expanding the range of services offered to tourists at museum events also increases the income of industries such as transport, trade, catering, household services and so on.

\section{Conclusions}

The organization of event cultural and mass actions is carried out according to the fulfilled technology allowing to consider all details. This takes place in five stages: preliminary, preparatory, rehearsal stage, script debugging and equipment adjustment, event stage, reflexive stage.

Event marketing is one of the key tools for promoting brands and sellers in the market in today's environment, when the information environment is oversaturated and traditional advertising relinquishes its former position. Event marketing is a set of marketing and advertising activities aimed at promoting the object, attracting a wider target audience, carried out in connection with any event. Thus, today it is event events, or event events, that demonstrate the greatest effectiveness as a means of informing the target audience about existing and emerging brands, goods and services.

The effectiveness of events is based on a psychological phenomenon, which can be described as the formation of a connection in the emotional sphere of the consumer between an object (brand, product, service) and positive emotions. Accordingly, the main purpose of the event is not obsessive information about goods and services, but to create positive vivid emotions and memories of participants, which will later be associated with the brand and force them to return to it in various forms of consumer behavior.

Event events as a tool for promoting brands and services have a number of advantages:

1) They are unobtrusive and interesting, which distinguishes them from advertising; the attention of potential consumers or partners is attracted by the event itself, its content, while 
the recognition of the brand and new products and services has a side effect;

2) They are convenient because they have the flexibility and ability to respond in the course of events, which allows you to take into account the interests of a particular audience and work with it;

3) Event events have a longer-lasting effect, as they not only inform about new opportunities, but also form the image of the brand, fixing its image in the minds of consumers or potential partners; that is, event marketing focuses on strategic planning, not tactical;

4) Event activities are beneficial in any case, as a negative result is also an important indicator; if the event is successful and effective, the main goals are achieved: media attention is attracted, the target audience creates a positive image of the company, brand; promising contacts and relationships can be established; failure of the event provides material for analysis, identification of errors and problems, and then - to clarify and adjust the strategy.

There are three types of events: informational, business and entertainment.

Informational events are focused on informing the target audience, bringing them new and useful information, such as a new product launched on the market, new services or technologies, etc. Information events can take place in the format of a presentation, exhibition, film screening, lecture, etc.

Work activities are aimed at sharing experiences, developing the image of the brand or company, improving the professional level and morale of employees. Such events take place in the form of conferences, forums, team-building trainings, etc.

Entertainment events are needed to draw attention to the brand, company, product, to increase the audience and increase demand. According to their goals, such activities should be classified as informational. But to achieve the goals, several other means are chosen, including the entertainment component that comes to the fore. Sometimes such events are called leisure. They can take place in the format of holidays, concerts, games, quizzes, shows, etc.

Event events as a means of informing the target audience, attracting attention, promoting the brand and creating the company's image have some features.

1) The event should be clearly focused on the target audience, which can become customers of the company or a consumer of a new product or service. If the target audience of the company is one, and the event is another, then the idea completely loses its practical meaning.

2) It is not enough to simply mention a brand or company name at an event. It is important that the event is thematically related to the services or goods being promoted, that is, it should evoke certain associations that will form an emotional attachment.

That is, from the standpoint of the economy, the event has certain economic functions: it attracts new potential buyers, customers and partners. However, event events, due to their nature and special content, include a clear socio-cultural aspect. From the point of view of socio-cultural activity, the emphasis shifts somewhat when considering an event.

For the further development of event museum events is the introduction of forms of state support, tour operators and investors.

\section{References}

1. F. Fathy, Y. Mansour, H. Sabry, M. Refat, A. Wagdy, Solar Energy, 204(1), 673-682 (2020), doi.org/10.1016/j.solener.2020.05.014

2. C. Fenu, F. Pittarello, International Journal of Human-Computer Studies, 114, 20-35 (2018), doi.org/10.1016/j.ijhcs.2018.01.009 
3. B.I. Farahat, K.A. Osman, HBRC Journal, 14(1), 66-78 (2018), doi.org/10.1016/j.hbrcj.2016.01.004

4. X. Luo, P. Song, Y. Wang, W. Tian, Z. Gu, Energy Procedia, 104, 431-436 (2016), doi.org/10.1016/j.egypro.2016.12.073

5. M. Napp, T. Kalamees, T. Tark, E. Arumägi, Energy Procedia, 96, 592-600 (2016), doi.org/10.1016/j.egypro.2016.09.105

6. J. Pallud, D. W. Straub, Information \& Management, 51(3), 359-373 (2014), doi.org/10.1016/j.im.2014.02.010

7. S. Karampela, D. Kavroudakis, T. Kizos, Current Issues in Tourism, 22(12), 14601479 (2019), doi:10.1080/13683500.2017.1379475

8. T.Y. Dewanti, D. Susiloningtyas, IOP Conference Series: Earth and Environmental Science, 355(1), 0120553rd (2019), doi:10.1088/1755-1315/355/1/012055

9. S. Li, C. Li, C., J. Li, Asia Pacific Journal of Tourism Research, 24(11), 1079-1091 (2019), doi:10.1080/10941665.2019.1665556

10. J. Cheng, X. Jing, H. Zhenfang, Habitat International, 87, 1-10 (2019), doi:10.1016/j.habitatint.2019.03.011

11. C. Sami, Journal of Destination Marketing \& Management, 11, 183-191 (2019), doi:10.1016/j.jdmm.2017.09.002

12. V. Nicula, S. Spânu, R.E. Neagu, Procedia Economics and Finance, 6, 530-541 (2013), doi:10.1016/S2212-5671(13)00171-8

13. D.D. Fundeanu, Procedia Economics and Finance, 23, 744-749 (2015), doi:10.1016/S2212-5671(15)00501-8

14. H.A.M. Shaffril, A. Hamzah, S.M. Yassin, et al., Asia Pacific Journal of Tourism Research, 3 (20), 295-313 (2015), doi:10.1080/10941665.2013.877048

15. S. Wang, K. Hung, International Journal of Hospitality Management, 48, 92-101 (2015)

16. V. Ivanov, S. Popov, N. Dontsov, et al., E3S Web of Conferences, 175, 05023 (2020)

17. V. Provotorina, L. Kazmina, A. Petrenko, G. Ekinil, E3S Web of Conferences, 175, $10002(2020)$

18. G. Ekinil, L. Gorgadze, and O. Yuryeva, E3S Web of Conferences, 210, 18050 (2020)

19. A.M. Walder, Studies in Educational Evaluation, 54, 71-82 (2017), https://doi.org/10.1016/j.stueduc.2016.11.001

20. J.C.-C. Chow, C.Ren, B. Mathias, J. Liu, Children and Youth Services Review, 101, 217-224 (2019), https://doi.org/10.1016/j.childyouth.2019.04.008Get rights and content

21. M. Keinänen, J. Ursin, K. Nissinen, Studies in Educational Evaluation, 58, 30-36 (2018), https://doi.org/10.1016/j.stueduc.2018.05.007Get rights and content

22. V. Ellis, A. Childs, Teaching and Teacher Education, 77, 277-28 (2019), https://doi.org/10.1016/j.tate.2018.10.020Get rights and content

23. N.C. Jackson, Business Horizons, 62, 761-772 (2019), https://doi.org/10.1016/j.bushor.2019.08.002Get rights and content

24. G. Ekinil, L. Gorgadze, V. Provotorina, A. Petrenko, IOP Conference Series: Materials Science and Engineering, 1001(1), 012118 (2020), doi:10.1088/1757899X/1001/1/012118

25. G. Ekinil, V. Provotorina, A. Petrenko, L. Gorgadze, E3S Web of Conferences, 217, 05006 (2020), doi.org/10.1051/e3sconf/202021705006 